\title{
İSLAM ÖNCESİ TÜRK TOPLUMUNDA KADININ KONUMU ÜZERINE
}

\section{İbrahim TELLİOĞLU*}

\section{$\ddot{O} z$}

Toplumların uygarlık seviyelerinin belirlenmesinde cemiyet hayatında kadın ve çocukların konumu önemli bir yer tutar. En ilkel cemiyet hayatından günümüze bu iki grubun hakları, esasında toplumların insan haklarına bakışını da anlamaya yarar. Ataerkilliğin baskın olduğu İlk Çağ medeniyetlerinde kı çocuklarının öldürülmesi, ömür boyunca birinin vesayetinde yaşaması ya da isim verilmeye layık görülmemesi gibi durumlar cinsiyet ayrımcıllğının ulaştığı boyutu gösterir vahim örneklerdir. Aynı şekilde kadın öldürüldüğünde katilin hiçbir cezaya çarptırılmadığı toplumlar olduğu gibi kadın ve çocukların baba için çalıştığı, kocasının kadını istediği zaman boşayabildiği durumlara da sıkça rastlanır. Bunların yaşandığı zamanlarda Türk toplumunda kadının yerinin ne olduğu konusu Türklerin medeniyet tarihindeki yerini belirleyici önemli bir ölçü olacaktır. Kadının aile ve cemiyet içerisindeki yerinden başlamak üzere siyasi ve hukuki hakları ile birlikte ele alınabilecek mesele aydınlığa kavuşunca, göçebe olmakla küçümsenen ve uygarlık tarihine katkısı olmadığı ön kabulü ile hakkında önermeler üretilen Türklerin tarihteki gerçek yeri de gün yüzüne çımaya başlayacaktır.

Anahtar Sözcükler: İslam öncesi dönem, Türkler, kadın, sosyal statü, hukuki durum, ekonomik haklar.

\section{UP ON THE POSITION OF THE WOMAN IN THE PRE-ISLAMIC TURKISH SOCIETY}

Abstract

The position of the women and the children play an important role in determination of the level of the civilisation of the society. The rights of both groups actually provide a better point of view of the societies towards human rights from the most primitive societies up to now. In the dominant patriarcial structure in the ancient civilisations the killing of the girls, their living under the custody of someone or not being regarded to be given a name are the bad examples of indication that displays the dimension of the sex discrimination. Similarly it a common fact that there are societies when a woman is killed the murderer is never punished and the woman and children work for the father and the husband gets divorced form his wife whenever he wants. During these times when all these are experienced what the position of the woman in the Turkish society is will be an important criteria to determine the place of the Turks in the history of civilisation. When the matter starting from the point of the position of the woman in the family and the society together with political and legal rights is illuminated the position of the Turks who are despised as nomadic and about whom some ideas are fabricated claiming that they did not contribute to the history of civilisation with some prejudices will start to come to the fore.

Keywords: The pre-Islamic period, Turks, woman, social status, legal situation, economic rihgts.

*Prof. Dr.; Ondokuz Mayıs Üniversitesi Fen-Edebiyat Fakültesi Tarih Bölümü, telliogluibrahim@gmail.com. 
Eski Türk toplumu ile ilgili özellikle batılıların hazırladığı eserlerin pek çoğunda, Türklerin göçebe olduğundan hareketle çeşitli önermeler üretilmiştir: Göçebe olmalarından dolayı ilk büyük medeniyetler içerisinde yer alamayan Türkler, insanlığın gelişimine neredeyse hiç katkıda bulunmamış bir topluluktur. Vahşi aile grupları şeklinde örgütlenmiş göçebe çobanlardır. Doğuştan itibaren medeni vasıflardan yoksun olan Türklerin de içerisinde yer aldığı göçebeler, sadece var olanı tüketir ve bu anlamda hayatı kolaylaştıran gelişmelerin önünü tıkar. Askerî güçleri ile bir yeri ele geçirseler de o ülkede fetret devri başlatırlar, karmaşa çıkarmanın ötesinde bir şey yapmazlar. Herhangi bir inanç sisteminden yoksun olmalarından dolayı başıboş insan yığını olarak tarif edilmelerinde mahzur yoktur. Devlet teşkilatına sahip olmadıkları gibi kanun nedir bilmezler, kendi kurallarına göre yaşamayı severler (Kafesoğlu, 1988, s. 32-33). Bu ve benzeri önermelerle eski Türkleri tanımlamaya çalışan düşünürlerin yanıldığı günümüzde açıkça ortaya çıkmıştır.

İslam öncesi Türk toplumu yarı göçebeydi. Ekonomik sistem büyük ölçüde hayvancılık üzerine kuruluydu. İlk dönemde boylar hâlinde yaşayan Türkler, devletlerin ortaya çıkması ile birlikte milletleşmeye başlamıştı. Atı ehlileştirmeleri ve demiri ilk kullanan topluluklardan biri olmaları sebebiyle uygarlık tarihine büyük katkı yapmışlardı. Süvari orduları sayesinde yaşadıkları coğrafyalarda çok zorlanmadan siyasi üstünlük kurabilmişlerdi. Kendilerini medeniyetin merkezi olarak kabul eden Çinlilerden tutun da Avrupalı topluluklara kadar pek çok farklı unsur Türk ordu sistemini örnek alarak askerî yapılarını yeniden düzenlemişlerdir. Ayrıca kurdukları güçlü devletler sayesinde Çin sınırından Atlas Okyanusu'na kadar pek çok farklı topluluğu bayrakları altında bir arada yaşatmışlardır.

Türklerin siyasi ve askerî meziyetlerini kabul eden bazı düşünürler, sadece bu vasıfları ile kıymet görebileceklerini, göçebe olmalarından dolayı uygarlık tarihinde yer edinemeyeceklerini savunurlar. Onlara göre Türklerin de içerisinde bulunduğu göçebeler her türlü medeni gelişmeden uzak, sadece başkalarının ürettiğini kullanan hatta yeri geldiğinde onları yok eden bir topluluk konumundadır. Ancak bazı arkeolojik çalışmalarda ele geçen buluntular onların bu tarih görüşünü tozlu raflara kaldırmıştır. Pazırık kurganında ele geçen buluntulardan dünyanın en eski halısının Türkler tarafından yapıldığı ortaya çıkmıştı. Esik kurganında ortaya çıkan altın elbise ise $M O ̈ \mathrm{~V}$. yüzyılda Türk madenciliğinin geldiği ileri seviyeyi ve sahip oldukları estetik değerleri gösterir önemli bir örnek olarak göz önündedir. Sadece bu iki örnek bile medeniyet tarihindeki Türklerin yeri ile ilgili algıyı büyük ölçüde değiştirmeye yetmiştir. 
Devlet kurabilmenin en önemli şartlarından birisi insanları bir arada yaşatacak kanunlara ve güçlü bir toplumsal yapıya sahip olma ise, Türkler bu açıdan büyük ilerleme kat etmiş olmalıdır. Zira İslamiyet'ten önceki devirde Orta Asya'dan dünyanın farklı yerlerine dağılarak Hindistan'dan Karadeniz'in kuzeyine, Macaristan'dan Kafkasların güneyine birbirinden çok farklı yerlerde devletler kurma başarısını gösteren bir millet, siyaseten başarılı olmalıdır. Farklı kökenlerden, dinlerden, kültürlerden insanları bir arada yaşatacak siyasi birikime ve kanuni alt yapıya sahip olmalıdır. Dünyayı yönetmek maksadıyla yaratılmış bir millet olduğuna inanan Türkler, cihan hâkimi olabilmek için bu birikime ve hukuka büyük önem vermişlerdir (Turan, 1980). Ancak bu ideale ulaşabilmek için güçlü bir sosyal yapıya da ihtiyaçları vardır ki güçlü bir toplumun temeli güçlü bir aile oluşumundan geçer.

Türk ailesi ataerkildir (İnan, 1998, s. 341). Ancak Türklerdeki ataerkillik çeşitli farkları dolayısıyla pederşahi yerine pederi olarak adlandırılan türdendir. İran ya da Roma'da olduğu gibi babanın mutlak hâkimiyeti söz konusu değildir. Kadının ve çocuğun çeşitli hakları olduğu bir aile çeşididir (Onay, 2012, s. 350). Konargöçerliğin bir neticesi olarak çekirdek aile tipi yaygındır. Çok evliliğin pek görülmediği eski Türk toplumunda genellikle dıştan evlilik vardır (Ögel, 1988, s. 237). Aile, dinî ve toplumsal değerlerle kutsanan bir kurumdur. Yeni bir ev kurmak anlamına gelen ve günümüze kadar kullanılan ev - bark olma deyimindeki bark kelimesi mabet demektir. Yeni bir aile kurulması mabet kadar kutsal bir çatı inşa edilmesi anlamına gelir (Gökalp, 1991, s. 231-232). Aile ve toplum içerisinde kadının yeri ise Türklerin medeni seviyesini gösteren önemli bir ölçüdür.

İslam öncesi dönemde Türklerde aile yapısı ve kadının statüsü ile ilgili bugüne kadar pek çok çalışma yapılmış ve mesele etraflıca ele alınmıştır (Eröz, 1977; Sevinç, 1987). Ancak bu külliyat içerisinde birbirinin tekrarı mahiyetindeki pek çok tespitin tarihî temeli olup olmadığı konusunda çok durulmamıştır. Aynı şekilde özellikle kadının durumuyla ilgili meseleler ortaya konulurken bazı olaylar görmezlikten gelinmektedir. Buna bağlı olarak konu oldukça idealize edilerek işlenmektedir. Bu çalışmada daha önce yapılan karşılaştırmalı metot takip edilerek Türk kadınını çağdaşlarıyla kıyaslanıp nasıl bir konuma sahip olduğunu tasvir edilecektir. Bu yapılırken ihmal edilen bazı tarihî olaylar ve kavramların altı çizilerek meseleye çok yönlü bakılmaya çalışılacaktır.

Türklerde kadın ya da aile meselesi gündeme geldiğinde Ziya Gökalp'in görüşleri üzerine kurulan önermelerle karşılaşılır. Türklerin hem demokrat hem de feminist olduklarını kaydeden Gökalp, Şamanizm'in kadındaki kutsi kuvvete dayandığını yazar. Türk şamanları 
sihir ile olağanüstü güçlerini gösterebilmek için kadınlara benzemeye çalışırlarmış. Bu inanç içerisinde toplum hayatında kadınla erkeğin bir arada bulunması şartmış. Ona göre velayet-i amme Hakan ile hatunun bir arada olması suretiyle tecelli ettiği için bir emirname yazıldığında "hakan emrediyor" ibaresiyle başlarsa kabul olunmaz "hakan ve hatun emrediyor ki" sözüyle başladığında muteber sayılıyormuş. Hakan tek başına bir elçiyi huzuruna kabul etmez sağda hakan solda hatun oturduğu bir zamanda huzura alınırdı. Şölenlerde, kinkeşlerde, kurultaylarda, ibadet ve ayinlerde, harp ve sulh meclislerinde, hatun da mutlaka hakanla beraber bulunurdu. Kadınlar hükümdar, kale muhafızı, vali, sefir olabilirdi (Gökalp, 1990, s. 158-159).

Ziya Gökalp'in tespitlerinden hareket eden pek çok düşünür biraz da meseleyi idealize ederek Türklerin kadına büyük değer verdikleri, toplumsal, dinî, hukuki ve siyasi bakımdan emsalsiz imkânlara sahip olduğunu kaleme almışlardır. Ancak bardağa o kadar dolu tarafından bakılmaktadır ki Gökalp'in “hakan ve hatun emrediyor ki” diye yazılmadan kanunların geçerli olamayacağı düşüncesine kimse bir yazıt ya da kaynaktan destek bulma ihtiyacı hissetmemiştir.

Cinsiyet ayrımcılığı İlk Çağ’dan günümüze insanlığın en önemli toplumsal problemlerinden birisidir. Tarih boyunca dünyada genel olarak kadına yönelik negatif ayrımcılık yaygındır. Toplumsal farklılıklar bulunmakla birlikte doğumdan itibaren çocuklar arasında cinsiyet ayrımı yapılması âdeta geleneksel hâle gelmiştir. İslam öncesinde Türklerin çağdaşı toplumlarda bu durum kendini gösterir. Mesela Türklerin en yakınındaki kültürlerden birisi olan Çinlilerde doğan çocuk kız ise isim verilmeye değer görülmez, ona sayı ile hitap edilir. Yakın coğrafyadaki diğer bir topluluk olan Hintlilerde çocuk kız ise evlenene kadar babasının eğer yoksa erkek kardeşlerinin himayesi altındadır. Bu himayeden maksat kızların zayıf karakterli, günaha meyilli ve hayatını tek başına devam ettiremeyecek kadar güçsüz olduğuna inanılmasıdır. Ancak bu konudaki en uç örnek Araplardadır. Araplar için doğan çocuk kız olursa bu bir utanç olarak kabul edilir. Bu yüzden kız çocuklarını diri diri toprağa gömenlere bile rastlanılır (Çağatay, 1989, s. 135). Buradan anlaşılacağı üzere Türklerin çağdaşı topluluklar farklı derecelerde de olsa çocukları arasında cinsiyet ayrımı yapmaktaydı. Hâl böyleyken Türkler çocuklarına farklı davranmazlar. Kutadgu Bilig'de Ay-Toldı oğlu Öğdülmiş’e nasihat verirken oğul ve kız kelimelerini yan yana kullanır. "Oğul-kız hakikatte gören gözün nurudur" diyen vezirin sözü (Yusuf Has Hâcib, 2003, s. 94) ile de cinsiyet ayrımı bilmediklerini gösterir. ${ }^{1}$

\footnotetext{
${ }^{1}$ Kutadgu Bilig'deki tespitlerin tamamı Türklerin kadınlara bakışı hususundaki görüşlerini tam yansıtmaz. Zira yukarıda çocuklar arasında cinsel ayrım yapılmadığıyla ilgili örnek verilen eserin Öğdülmiş'in, Ogdurmış’a çocukların nasıl terbiye edileceği yönündeki kısmında (s. 326-327) doğan çocuğun kız olmasından üzüntü duyulduğu anlatılmaktadır. Aynı bölümde kadınların mümkün olduğunca evden çıkmamasının faydalı olacağına dair ikazlar da
} 
Aynı şekilde Dede Korkut hikâyelerine bakıldığında çocuklar arasında cinsiyet ayrımı yapıldığına dair bir örneğe rastlanılmaz. Sadece soyun devamını sağladığı için erkek evlada daha çok meyledildiği hissettirilir. Ergenlik çağına kadar kız ve erkek çocuklarının bir arada yetiştirilmesi bu toplumsal değerin en önemli uygulamasıdır (Ergin 1988).

Türklerin çocukları arasında cinsiyet ayrımı yapmaması onların kadına bakışları hakkında önemli bir göstergedir. Çocukluk safhasından sonraki değerlendirmelere bakıldığında ise toplumun bu konudaki mental değerleri daha da netleşmeye başlar. Genç kız, evli kadın ve anne simgeleri üzerinden yapılan anlamlandırmalar başlangıç evresindeki bakışın ilerleyen dönemde de devam edip etmediğini belli eder. Bunun için toplumun en eski değerlerini yansıtan sözlü kaynaklar oldukça kıymetlidir. Kadınların toplum içerisindeki itibarı milletin zihin dünyasındaki yeriyle yakından alakalı olduğundan milletin düşünce sistemini asırlar boyu kuşaktan kuşağa aktaran sözlü kaynaklara bakmak gerekir.

Toplum hafızasının gidebildiği en eski yer olan efsane ve destanlar Türklerin kadına bakışını gösterme açısından oldukça kıymetli bilgiler içerir. Destanlara bakıldığında kahramanların anneleri ve eşleri hep ilahi 1şıktan varlıklar olarak tasvir edilir. Bu semavi sembol, kadının kıymetli bir varlık olduğunun işareti olarak kabul edilir. Oğuz Kağan Destanı'nda Oğuz Han'ın eşinin karanlık bastığında gökyüzünden inen, aydan ve güneşten parlak bir 1şık şeklinde tasvir edilmesi (Bang-Rahmeti, 2012, s. 93), Göç Destanı'nda Hulin Dağı'ndaki bir ağaca inen mavi bir 1şıktan Sungur, Kutur, Tükel, Ur ve Bögü Tigin'in doğması gibi örnekler bu duruma işaret eder (Banarl1, 1971, s. 28). Diğer taraftan Tanrı Ülgen'e yaratma ilhamını bir kadının vermesi de dikkat çekicidir. O yüzden bu ilhamın sahibi gün ana, kadınların temsilcisi olarak Tanrı katında erkeklerden daha yüksek bir konumdadır (Uraz, 1994, s. 88-89). Ayrıca ulusu koruduğuna inanılan ve kendisine ulus anası denilen Ana Maygıl isminde bir ruh olduğunu düşünürler (Çoruhlu, 2000, s. 44). Bu örnekler toplumsal hafizada kadının konumlandırılmasıyla ilgili olarak oldukça kıymetlidir. Fizik ötesi simgelerle anılması kadınlara cinsel bir obje olarak değil sıra dışı bir varlık muamelesi yapıldığının göstergesidir. Aynı şekilde inanç dünyasında kadının Tanrı'ya daha yakın bir konumda tutulması onların hukukunun dinî kurallarla belirlendiği sonucunu ortaya çıkarır.

Umay simgesi, Türklerin zihin âleminde kadına verilen kıymetin en önemli göstergelerinden birisidir. İlk kez Kültigin abidesinde “Babam kağan uçtuğunda küçük kardeşim

mevcuttur. Birbiriyle zit bu tespitlerin İslamiyet öncesi Türk toplumunda bulunduğuna dair tarihî örnek elde etmek pek mümkün değildir. 
Kül Tigin yedi yaşında kaldı... Umay gibi annem hatunun devletine, küçük kardeşim Kül Tigin er adını aldı." sözleriyle anılan Umay, Tonyukuk yazıtında Göktürkleri kurtaran ilahedir (Ergin, 1988, s. 25-26, 58). Tanrı Ülgen, ağaç ve orman kültünün en önemli sembollerinden olan kayın ağacını koruyucu ve merhametli ana Umay ile birlikte dünyaya göndermiştir (İnan, 1976, s. 39). Umay, kadın (anne) ve çocuklarla ilgili bir tanrıça ya da ruhtur. Hükümdarın hanımı Umay’1 temsil eder. Kadınları ve çocukları koruyan bir ruhtur. Her şeye hayat veren güneş de Umay'la ilgilidir (Çoruhlu, 2000, s. 39-41). Diğer yandan Türk mitolojisinde güzellik ilahesi olarak kabul edilen Ayzıt toplumsal bilincin görünüşü olarak erdem, ahlak, fazilet timsali bir sembol şeklinde tasvir edilirken fiziki özellikleri hiç anılmayan bir motiftir (Gökalp, 1991, s. 118; İnan, 1976, s. 26-27). Aynı şekilde Dede Korkut hikâyelerinde kadınlara yönelik hitaplar hep onure edicidir, incitici herhangi bir ifadeye rastlanılmaz (Ergin, 1994; Şen, 2008). Yenisey'deki Köktürk harfli yazıtlardan anlaşıldığı kadarıyla "Evdeki eşime, vadideki oğullarıma doyamadım, değerlilerime, kutsal devletime, baştaki begime doyamadım." örneğinde olduğu gibi kadının adı ilk sırada anılır. Kişi kelimesi ile insan ve her iki cins de ifade edilebildiği için kadın - erkek arasında bir ayrım olmadığı anlaşılabilir (Useev, 2012, s. 60-65). Türkistan'da ele geçen heykellerde aynı mezar alanına defnedilen kadın ve erkek heykellerinin bir arada olması bu eşitliğe şehadet eder (Alyılmaz ve Alyılmaz, 2014, s. 17). Kadınların ailesine ve eşine bağlılığı hususunda pek çok örnek vardır. Şorların Ak-Kağan destanında üç kadın tipine rastlanılır. Birincisi mücadeleci ve korkusuz Alp kadın tipidir. İdeal bir eş ve anne olarak tanımlanan kadınların üçüncü yönü ise aklın ve bilgeliğin sembolü olmasıdır (Bars, 2014, s. 109-110). Dede Korkut hikâyelerinden Deli Dumrul hikâyesinde eşinin onun için canını vermeye hazır olması eşe bağlılığın bir göstergesidir (Ergin, 1988, s. 126). İbn Fadlan'ın Türkler arasında gayrimeşru ilişkilerin olmadığı yönündeki tespiti de (İbn Fazlan, 1975, s. 31) çağdaşı toplumlarda ciddi biçimde cinsel meta hâline gelen kadınların Türk toplumu içerisindeki farklılığını göstermesi bakımından önemlidir.

Eski Türklerde kadınların sahip olduğu hukuki hakları çağdaşlarından daha ileri olduğu konusundaki kanaatleri güçlendirir. Bu konuda ilk dikkat çeken şey ekonomik bakımdan pek çok imkâna sahip olmasıdır. O zamanın şartlarında bu çok önemli bir hadisedir. Ziya Gökalp, evin karı ve kocanın ikisine birden ait olduğunu ifade ederek çocuklar üzerindeki velayet-i hassanın baba kadar anaya da ait olduğunu vurgular. Kadınlar emvâle tasarruf ettikleri gibi dirliklere, zeametlere, haslara, mâlikânelere de mâlik olabilirlerdi (Gökalp, 1990, s. 159-160). Diğer bir konu ise mirastan pay alma meselesidir ki bu hususta sadece çağdaşlarından değil 
günümüzdeki pek çok toplumdan da daha öndedir. Evlilik aşamasında kız çocuğu mirastan payını alırdı ve çeyiz malı üzerinde kocasının hiçbir tasarruf hakkı yoktu (Çimen, 2008, s. 196). Aynı dönemde bırakın miras almayı anne ve çocuklarının baba için çalıştığı Mezopotamya toplumunun ya da kadının mirastan hiçbir hak iddia edemediği Roma hukukunun geçerli olduğu zamanda (Pugliese, 1957, s. 345) evlilik çağı gelen kız, miras payını alarak yuvasını kurardı. Bu hukuki bakımdan büyük bir ayrıcalıktı. Bugün bile kız evlatlara mirastan pay verilme hususunda çeşitli engellemeler olduğu düşünülürse o dönemde Türk kadınının ne derecede önemli bir yer edindiği anlaşılabilir.

Türk kadınının hukuki durumu ile ilgili diğer önemli bir husus boşanma hakkına sahip olmasıdır. ${ }^{2}$ Ataerkilliğin yaygın olduğu toplumlarda böyle bir hakka rastlamak mümkün değildir. Kadını her şart altında evliliğe mecbur bırakan zihniyet Türkler içerisinde mevcut değildir. Hatta eski Hind toplumunda olduğu gibi eşi ölen kadın, çocukları ya da ailesinden başka erkekler sahip çıkmazsa günah işleyebileceği ve hayatını devam ettiremeyeceği sebebiyle öldürülebilirdi (Donuk, 1980, s. 167). İşte böyle bir çağda Türklerde kadınlar eşlerinden ayrılabiliyordu. Bu örneklerden anlaşıldığı üzere kadınlar günlük yaşantıda statü sahibi, hakları dinî ve toplumsal değerlerle korunan bir konumda bulunmaktadır.

Kadınların konumu bu esaslar üzerinde şekillenmekle birlikte bazı hadiseler sebebiyle uygulamada çeşitli farklılıklar olduğuna da rastlanır. Kadının toplum içindeki rolünü anlatanlar, Mete Han'ın kurduğu orduda askerlerini disiplin altına alması örneği verilirken 1slık çıkaran okunu attıklarından birinin de hanımı olduğunu vurgulamazlar. Aynı şekilde Türklerde vatan sevgisinin temelleri ile ilgili olarak örnek verilen hadisede Tunguzlarla savaşmamak için olan eşini onlara yollamasından sonra “o benim malımdı” diyen Mete Han'ın bu sözü görmezlikten gelinir. ${ }^{3} \mathrm{Bu}$ örneklerden anlaşıldığı üzere Türklerde kadının aile ve toplum hayatındaki hukukunun zaman zaman çiğnendiği de görülmektedir.

\footnotetext{
2 Divanü Lûgat-it Türk’te, “uragut başın yoldı" (kadın başını kurtardı) ifadesiyle kadının mihrinden ve başka şeylerden vazgeçerek kocasından ayrıldığı yazılıdır (Kaşgarlı Mahmud, 1999, s. 64).

${ }^{3}$ Yukarıda anılan örneklerin birincisinde Mete, barış rehinesi olarak Yüeçilerin elinde iken babası Teoman, eşinin baskısıyla diğer oğlunu tahta geçirmek maksadıyla Mete'nin öldürülmesi için Yüeçilere savaş açmıştı. Yüeçilerin elinden kurtulduktan sonra babasından intikam almak isteyen Mete, 1slık çıkaran oku icat ettikten sonra askerlerine, kendisi nereye ok atarsa oraya ok atmalarını emreder. Okunu çok sevdiği atına atar, bunu yapmayan askerlerini öldürtür, eşine atar, yapmayan askerlerini öldürtür, nihayet bir sürek avı sırasında babasına atar, askerleri de aynısını yapınca Teoman ölür ve Mete başa geçer. Diğer örnekte ise Hunlar daha yeterince güçlenmeden onları ortadan kaldırmak isteyen Tunguzlar, Mete ile savaşmak için bahane bulmaya çalışırlar. İlk olarak ondan atını isterler. Yanındaki beylerin karşı çıkmasına rağmen gönderir. İkinci olarak eşini isterler, yine etrafındakilerin muhalefetine rağmen yollar. Üçüncü olarak Hunlarla Tunguzlar arasındaki çorak bir araziyi isterler, çevresindekiler verelim demesine rağmen o, "at ve hanım benim malımdı ancak bu toprak milletimin malıdır, veremeyiz." der ve Tunguzlarla savaşır (Ban-gu, 2004, s. 5-6).
} 
Türklerde kadının aile ve toplumsal hukuk açısından konumu böyle gelişirken çağdaşı topluluklarda farklı uygulamalar görülür. Arap toplumunda kadınların hukuki hakları oldukça zayıftı. Bir erkek istediği kadar kadınla evlenebilir istediği zaman onları boşayabilirdi. Roma hukukunda Cumhuriyet devrinin sonlarına kadar baba ailenin mutlak hâkimi olduğu için koca karısını öldürebilir, satabilir, istediği zaman boşayabilirdi. Benzer biçimde Hintlilerde kadın evlendiğinde vesayeti kocasının üzerinde olurdu. Kocası öldüğünde oğulları ya da erkek kardeşleri bu vesayeti üstlenmediği zaman tek başına hayatını devam ettirmeyeceği ve günahkâr olabileceği ihtimaliyle kadın da öldürülerek onun yanına gömülürdü. Çin'de de bu vesayet sistemi devam ederdi ancak orada eşi ölen kadınlar büyük oğlunun koruması altına girerdi. Orta Çağ Avrupa'sında kadın günah sembolü olarak görülür, bir felaket ortaya çıktığı zaman bunun sebebinin günahkâr bir kadın olduğu varsayılırdı. Moğollarda anaerkil aile hâkim olmakla birlikte evlilikte kızın rızasına ihtiyaç duyulmazdı (Donuk, 1980, s. 148-161).

Kadınların toplumdaki siyasi konumu onların halk içerisindeki yerini gösterir önemli bir veridir. Türklerde özellikle hatunların siyasi gücü üzerinden çeşitli sonuçlara ulaşmak mümkündür. İlk defa Göktürkler zamanında Bumın Kağan'ın hanımının unvanı olarak kayıtlara geçen hatun ismi, devlet yönetiminde hak sahibi kadın anlamında imparatoriçe ya da kraliçe kavramını karşılar. Bazı tarihçilere göre Hunlar devrinden beri kullanılmaktadır. Hatun unvanı özel bir törenle alınır ve saraydaki diğer kadınlardan üstün sayılan bu kadınlar devlet idaresinde resmî yetki sahibi olup veliahtlar da genellikle onların oğulları arasından seçilir (Donuk, 1988, s. 30-31).

Hatunların toplum içerisindeki yerini gösteren en büyük örnek onlara ait şehirlerdir. Hatun şehirleri ismiyle bilinen bu şehirlerin kökeni, Türk beyleri sefere giderken kadın ve çocukların girilmesi güç, muhafazalı uzak vadilere çekilmesi sonucu oluşmuştur. Genellikle vadi tabanlarında olup su ve otlak bakımından elverişli bu şehirler yerler sarp dağ vadilerinde hatta göller içerisindeki adalarda bile olabiliyordu. Kuy olarak adlandırılan bu yerin Tuva lehçesinde ordu ile anılması, hükümdarın kadınlarına mahsus karargâhı olduğunu gösterir. Zamanla bu yerlere çeşitli tesisler kurulmasıyla hatun şehirleri oluşmuştur. Hunlar zamanından beri hükümdarın otağı ile hatun şehirlerinin var olduğu bilinmektedir. Hatun karargâhı çevresinde zamanla ortaya çıkan bu şehirlerden farklı olarak oğulların ikamet ettiği yabgu şehirleri de vardı. Hazarların başkenti Etil şehrinde hatunun oturduğu kısım Hatunbalıg olarak kaydedilmiştir. Uygurlar zamanında dört tane hatun şehri olduğu bilinir. Bunlar, Etsin-göl civarındaki Hatun-sını, Sarı ırmağın kuzey büklümü civarındaki K'o-tun Ch'eng, Kerulen 
nehrinin kaynağı yakınındaki Tolgoy-balgas, sonuncusu da Orhun bölgesindeki K'o-tun Ch'eng idi. Bu şehirler, Türk içtimai hayatının kadına verdiği değerin açık bir gerçeğidir (Baykara, 1997, s. 53-62).

Hatunların siyasi hayat içerisindeki yeri hakkındaki ilk bilgiler Çin kaynaklarından elde edilir. VIII. yüzyılın ilk çeyreğine kadar Türkler kendilerinden bahseden kaynak bırakmadığı için Çin tarihlerinden elde edilen bilgiler sayesinde kadının o dönemdeki konumu hakkında fikir edinmek mümkündür. Çinli tarihçilerin yazdıklarına bakılırsa Türklerde hükümdar eşleri devlet meselelerinde görüşlerini açıktan beyan ederlerdi. Devlet teşkilatı içerisinde hatun, kağandan sonra gelen en önemli güçlerden birisiydi. En önemli yasama organı olan Meclis (toy) üyesi olan hatunlar hükümdara vekâlet edebilir, ordu komutanlığı yapabilirdi. Hatunların hizmetinde görev yapan bakanlar vardı (Kafesoğlu, 1988, s. 258). Kağanın yanında hatunun mezarının bulunması devlet yönetiminde kadının erkeğin yanında olduğunu gösterir önemli bir örnektir (Alyılmaz ve Alyılmaz, 2014, s. 17).

Çin kaynaklarında Türk kadınının siyasi konumu ile ilgili ilk somut örnek Büyük Hun hükümdarı Mete'nin hanımı ile ilgilidir. Bu bilgi Ban-gu'nu kaleme aldığı onun ölümünden sonra kız kardeşi Ban-cao tarafından tamamlanan Han Sülalesi Tarihi'nde yer alır. I. yüzyılda hazırlanan ve MÖ 206 - MS 23 yılları arasındaki olaylardan bahseden bu eserde Hunların siyasi, ekonomik, sosyokültürel ve dinî hayatları ile ilgili önemli analizler yer alır (Tang Chi, 1971, s. 184-185). O zamana kadar kendilerini medeniyetin merkezine yerleştiren bir bakış açısıyla diğer bütün toplumları barbar olarak tanımlayan Çinliler, ilk kez bir topluma özel isim vererek onları nitelemekteydi. Hsiug-nu adıyla andığı Hunları tarif eden Çinli tarihçiler, onları tanıtma çabası içinde bütün özelliklerinden bahsetmeye çalışmaktaydı. İşte bu kapsamda hazırladıkları 120 ciltlik eserin 94. bölümünde yoğun olarak Türklerden bahsetmektedir. Hunların kökeninden tutun da geçim kaynaklarına, göçebeliklerinden tutun da günlük yaşamlarına kadar pek çok konuya 1şı tutan Çin kaynağı, iki taraf arasındaki bir savaş vesilesiyle Türkler arasında kadınların siyasi konumunu hakkında da çok önemli bir örnek verir: $M O ̈$ 201'de İmparator Kaoti, 320.000 kişilik büyük bir orduyla beraber Hunların üzerine yürümüştü. Maksadı kuzeyden ülkesine yönelen Hun akınlarına bir son vermekti. Mete Han sahte ricat taktiği ile küçük birlikler hâlinde Çin ordusuna saldırıp sonra geri çekilerek onları kuzeye doğru çekmeye başlamıştı. Büyük kısmı piyadelerden oluşan Çin ordusu bu takip sırasında büyük tahribata uğramıştı. Nihayet Mete Han Çinlileri Pai-teng dağında kuşattı. İmparator dört bir tarafının Hunlar tarafından kuşatıldığını fark ettiğinde iş işten geçmişti. Çinliler kurtulmak için çareler 
aramaya başlamışlardır. Sonuçta Mete'nin hanımı aracılığıyla Hun hükümdarına ulaşmışlar ve onu ikna etmişlerdir. Hanımı, Mete Han'a, “ỉki hükümdar birbirlerine zorluk çıkartmamalı. Bugün Han topraklarını ele geçirseniz (bile), Şanyü, (siz) sonsuza kadar buralarda oturamazsınız." diyerek eşini Çinlilerle uzlaştırmaya çalışmıştır. Hatun'un dediklerini göz önünde bulunduran Mete, kuşatmayı kaldırarak Çin imparatorunun ülkesine dönmesine müsaade etmiştir (Han Hanedanlığı Tarihi, 2004, s. 10). Bu hadisede dikkat çekici iki husus vardır: Birincisi Çinliler, Tanrı'nın oğlu ve dünyanın en önemli gücü olarak gördükleri imparatorlarını bir kadından yardım istemeye ikna edecek kadar Türklerde kadının siyasi vasfını anlamışlardır. İkincisi, bir kadının aracılığıyla böylesine karmaşık bir durumdan kurtulabileceklerini var sayacak kadar Türklerin sosyokültürel yapısını çözmüşlerdir. Benzer bir durum Göktürklerde de olmuştu. Ekim 623’te İl Kağan Çinlilerin Mai şehrini kuşatmış ancak daha sonra kararını değiştirerek geri dönmek istemiştir. Çin kaynaklarının yazdığına bakılırsa eşinin 1srarı üzerine fikrinden vazgeçerek şehri kuşatmayı sürdürmüştü (Onay, 2012, s. 352).

Çinlilerin Hunların içtimai yapısı hakkında ayrıntılı bilgiler elde ettikleri Cang Çien'in raporuyla birlikte kadınların Türklerde ne kadar önemli olduğu da anlaşılır. Hunların ülkeleri üzerindeki baskısını hafifletmeye çalışan Çinliler, tek başlarına onları durduramayacağını anladıklarında müttefik aramaya başlarlar. Bu maksatla Yüe-çilerle anlaşma yapmak üzere General Cang Çien'i görevlendirilir. Hunları ve ülkelerini iyi tanıması sebebiyle bu işle görevlendirilen Cang Çien, $M O ̈$ 138'de seyahatine başlar. Ancak kısa süre sonra Hunlara esir düşer. Yaklaşık on yıl Hunların elinde tutsak kalan Çinli general, onlarla bir arada yaşar. Bu arada evlenir, çocukları olur. Ancak o, imparatoruna ve görevine sadakatini hiç bırakmaz ve on yıl sonra bulduğu ilk firsatta kaçar ve Yüe-çilerin yanına gider. O sırada Afganistan'ın kuzeyine inmiş olan Yüe-çiler tekrar Hunlarla mücadele etmeye yanaşmazlar ve Çin imparatorunun teklifini kabul etmezler. Geri dönüşte yine Hunlara esir düşse de bu sefer kısa süre sonra kurtulan Çinli general, imparatorunun huzuruna vardığında başından geçenleri ona anlatır. $\mathrm{Bu}$ elçilik görevi siyasi bakımdan başarılı olamamıştır ancak Cang Çien'in anlattıkları sayesinde Çinliler, Orta Asya'yı ve Hunları yakından tanıma firsatı bulmuşlardı (Ligeti, 1986, s. 51-54). Bu raporda Çinlilerin aksine Türklerin kadınlara büyük önem verdiklerini kaydeden General, bu durumdan faydalanarak Hunlar üzerinde nüfuz kurulabileceğini kaydetmektedir. Çin'de kadınların devlet ve toplum hayatında kayda değer bir ağırlığı olmadığı için Çinli generalin bu ikazı oldukça önemlidir. O yüzden Çinliler Türk hükümdarlarına kız vererek sarayda etkili olmaya çalışmıştır. Böylece annesi Çinli olanların tahta geçebileceği ve bu sayede Çinlilere 
düşmanlık beslemeyecek bir yapı oluşacağını umut etmekteydiler (Di Cosmo, 2002, s. 715). Türkler de bu plana karşı aldıkları önlem ile sadece baş hatundan yani Türk anneden doğanların başa geçebileceğini kural hâline getirmişlerdir.

Türk hatunlarının siyasi konumu ile ilgili olarak Çin kaynakları dışında en çarpıcı örnek Avrupa Hun Hükümdarı Attila'nın eşi Arıkan Hatun'a aittir. Bizans elçisi Priskos'un Attila'ya yaptığı elçilik sırasında Avrupa Hunları hakkında önemli bilgiler veren Priskos, onları dünyaya tanıtan en önemli kaynak konumundadır. Attila'dan sıradan bir Hun askerine kadar pek çok farklı kesit sunarak Hunların kim olduğunu Avrupalılara tasvir eden Priskos, onların gelenekleri hakkında da çok kıymetli bilgiler verir. Onun yazdıkları sayesinde Orta Asya'daki geleneklerin bir şekilde Avrupa'da da devam ettirildiği görülür. Çin kaynaklarının Mete'nin hanımı Yençi hakkında yazdıklarının bir benzerini Priskos da Attila'nın eşi Arıkan Hatun hakkında yazar. Hun hükümdarını sarayında ziyaret eden Bizans elçisi Arıkan Hatun'u kendi sarayında ayrıca ziyaret eder. Attila Roma heyetini maiyetiyle birlikte kabul ederken Arıkan Hatun da Priskos'u yanında hizmetinde olan memurlar ve hizmetkârlar ile birlikte kabul etmişti. Bu merasim hatunun statüsünü gösterme anlamında önemlidir. Arıkan Hatun'a getirdiği hediyeleri sunan Priskos, ertesi gün Han'ın eşi tarafından yemeğe çağırılarak onurlandırılacaktır (Ahmetbeyoğlu, 1995, s. 44, 50).

Avrupa Hunlarındaki bu uygulamanın farklı şekillerde de olsa Göktürklerde ve Uygurlarda da var olduğu anlaşılmaktadır. $725^{\prime}$ te Çin imparatorunun gönderdiği elçiyi Ötüken'de kabul edenler arasında Bilge Kağan'ın yanı sıra hanımı Po-fu da vardı (Gömeç, 1997, s. 83). Çin kaynaklarından öğrenildiğine göre Uygur kağanı Bilge Kağan'ın hanlık otağı Karakurum'un 70 mil kuzeybatısında iken hanımı prenses Chin-lien'in sarayı ondan 30 mil daha uzaktaymış (Ögel, 2002, s. 23-24).

Türklerin kendilerini anlattığı ilk Türkçe kaynak olan Orhun abideleri, kadının siyasi konumunu gösterir önemli bir örnektir aslında. Kültigin abidesinde ikinci Göktürk Devleti’nin kuruluşu anlatılırken, "Yukarıda Türk Tanrısı, Türk mukaddes yeri, suyu öyle tanzim etmiş. Türk Milleti yok olmasın diye, millet olsun diye babam İltiriş Kağanı, annem İlbilge Hatunu göğ̈̈n tepesinden tutup yukarı kaldırmış olacak." diye yazmaktadır (Orkun, 1987, s. 34). Burada Tanrı'nın Türk milleti yok olmasın diye yarattı̆̆ı kişiler arasında sadece kağanın değil eşi İlbilge Hatun'un da adının zikredilmesi, yeniden varoluş sırasında hatunun da kağan kadar seçilmiş olduğunu gösterir. 
Türk hatunlarının siyaseten gelebilecekleri en üst makama Sabir hükümdarı Boğarık Hatun sahip olmuştur. VI. yüzyıl başlarında Kafkasların güneyinde bağımsız hareket etmeye başlayan Sabirlerin başında Belek isimli bir hükümdarları vardı. Onun ölümünden sonra oğulları çok küçük olduğu için yerine eşi Boğarık Hatun geçti. Bizans kaynakları onun çok kudretli ve tedbirli bir kişi olduğunu yazar. Boğarık Hatun aynı zamanda 100.000 kişilik bir ordunun başkumandanı olmuştur (Baştav, 1941, s. 60-62) Böylece bu zamana kadar naiblik, toy üyeliği vs. görevlerinin ötesinde bir insanın siyaseten ulaşabileceği en üst makama gelmiştir.

Göktürkler zamanına ait diğer örnekler kadınların devlet başkanlığına vekâlet etmesiyle ilgilidir. Bir İslam kaynağında yazdığına göre Horasan valisi Ubeydullah b. Zeyd 674'te 24.000 askerle Beykend'i almaya geldiğinde bölge, Buhara'da bulunan Hatun tarafından idare edilmekteydi. Çevredeki Türklerden yardım almasına rağmen Müslümanlara yenilen Hatun daha sonra onlarla antlaşma yaptı (el-Belâzurî, 1987, s. 596-597). Bu hatun hükümdar soyundan Tuğşad'ın anası idi. Oğlu küçük olduğu için onun naibi sıfatıyla on beş yıl memleketini idare etmişti (İnan, 1976, s. 191). Bilge Kağan'ın ölümünden sonra önce oğlu İ-jan başa geçmiş fakat çok zaman geçmeden ölümü üzerine de Bilge Kutlug unvanlı Tengli tahta oturmuştur. Yeni kağanın yaşı küçük olduğu için devlet idaresini annesi aynı zamanda Tonyukuk'un kızı olan Pofu hatun üstlenmiştir. Vezirlerden Yü-ssu Tarkan ile iş birliği yaparak konumunu güçlendirmeye çalışan Po-fu Hatun, kağanın amcaları olan sol ve sağ şadları ortadan kaldırmak isteyince büyük bir huzursuzluk ortaya çıkmışı. Batı kanat şadını öldürmeyi ve halkıyla askerlerini kendisine bağlamayı başaran Hatun sol kanat şadı P'an Kül Tegin'in üzerine yürümeye hazırlanırken o erken davrandı ve Tengli kağanı öldürdü. Böylece Po-fu Hatun'un saltanatı da son buldu. Kısa süre sonra da Basmıl, Karluk ve Uygurlar ayaklanarak Göktürk devletine son verdi (Taşağ1l, 2004, s. 56-58)

VII. yüzyılda Uygurlarda görülen bir örnek kadınların hukuki konumunu gözler önüne serer. Uygur kağanlarının kız aldıkları Bugu boyu kağanlığın özellikle güney bölgelerinde büyük nüfuz sahibiymiş. Bu aile vesilesiyle Türkler arasında dayı ailelerinin veraset düzeni anlatılırken ana ailesinin öne çıkmasıyla ilgili olarak bir örnek verilir: 630'da Uygur boylarını bir araya getiren Pusa'nın annesi mahkeme başkanlığı yapmaktaymış (Ögel, 1988, s. 444). Bu zamana kadar kadınların siyasi konumlarıyla ilgili örneklerde hep onların devlet meseleleriyle ilgili işlerde görüş bildirdiği ya da çeşitli görevlere geldiği yazılmaktaydı. Ancak Uygurlardaki bu uygulama vesilesiyle kadınların hâkimlik yaptığı da öğrenilmiş oldu. 
Abbasi halifesi Muktedir-billah tarafindan İdil Bulgar Hanı İlteber Almuş’a gönderilen heyet içerisinde yer alan ibn Fadlan'ın gözlemleri, Türklerde kadının statüsü hakkında önemli ayrıntılar içerir. 12 Mayıs 922 Pazar günü Bulgar hükümdarının huzuruna varan heyet, Çarşamba gününe kadar halifenin mektubu okunurken hazır bulunmaları için çağırılan bey, kumandan ve aile fertlerini bekledi. Bu heyet içerisinde hükümdarın eşi de vardı. İbn Fadlan, kendilerinde görülmediği bir şekilde hatunun, hanın yanında oturduğunu ve bunun Türklerin âdeti olduğunu yazar. Halifenin mektubu okunduktan sonra yapılan törende ibn Fadlan, getirdikleri hediyeleri hükümdara ve eşine takdim ettiğini, bu iş bitince de halkın huzurunda hatuna hilat giydirdiğini yazar. Hatun hilat giyince kadınların onun üzerine gümüş para saçmasıyla tören son bulur (İbn Fazlan, 1975, s. 44-45). İbn Fadlan'ın yazdıkları sayesinde Hunlar vasitasıyla Avrupa'ya taşınan Türk geleneklerinin Bulgarlar zamanında da devam ettiği anlaşılmaktadır. Araplarda olmadığı şekilde Bulgar hatununun karşılamada bulunmasını Türklere özgü olarak nitelerken kendisi de farklı bir iş yaparak hükümdardan sonra eşine de hilat giydirmesi de onun için çok ilginç bir deneyim olmuştur.

Hatunların toplum içerisindeki yerini göstermesi bakımından Tonyukuk'un anlattığı bir örnek oldukça önemlidir. Tonyukuk yazıtında anlatılana bakılırsa Kapgan Kağan, Kırgız seferinden sonra Türgişler üzerine yürümek üzere iken hanımının ölümü üzerine ona cenaze merasimi düzenlemek için komutayı Tonyukuk'a bırakarak geri dönmüştü (Orkun, 1987, s. 110). Bu seferin Türkler arasında siyasi birliğin sağlanması ve Göktürklerin gücünü tescil ettirmesi bakımından büyük önem taşıdığı göz önünde tutulursa kağanın eşine verdiği kıymet anlaşılabilir.

Eski Türk toplumunda kadınların siyaseten bu kadar yüksek mevkilere yükselmesi annenin aile içindeki yerinden kaynaklanır. Babadan sonra aileyi anne temsil ettiği için annenin yeri babanın diğer akrabalarından daha ileri olurdu. Babanın mirası ve çocukların sorumluluğu anneye kalırdı. Kadınların hükümdar naibi ya da devlet içerisinde söz sahibi olmalarının sebebi buydu (Çimen, 2008, s. 204).

Bu bilgilerden anlaşıldığı üzere İslam öncesi dönemde Türklerde kadınların önemli bir konuma sahip olduğu anlaşılmaktadır. Ataerkil bir aile yapısının hâkim olduğu eski Türk toplumunda çocuklar arasında cinsiyet ayrımı yapılmaması, kadınların, doğuştan itibaren ortaya çıkan bazı eşitsizliklere maruz kalmadığını gösterir. Çağdaşı toplumlarda var olan ve kız çocuklarının utanç olarak görüldüğü geleneklere Türkler arasında rastlanılmaz. Türk kızlarının 
evleneceği eşi kendisinin seçmesi ve evlilik sırasında baba evinden miras payını alarak çıkması da onun ailesi içerisinde belirli bir hukuka sahip olduğunun delilidir.

Türk kadını anne olduktan sonra statü olarak çeşitli yeni haklar elde etmektedir. Ev ve tüm servet karı - kocanın ortak malı olduğu için bunlar üzerinde tasarruf hakkı eşinden sonra kadınlara geçerdi. Bu sistem devlet yönetiminde de kendini gösterdiğinden eşleri öldükten sonra devlet idare eden kadınlara rastlamak mümkündür. Diğer yandan kadınların boşanma hakkına sahip olması onları her şart altında evliliği devam ettirme mecburiyetinden kurtarır. Bu iki vasfı dolayısıyla Türk kadını sadece çağdaşı topluluklardaki kadınlardan değil günümüzdeki pek çok hemcinsinden de ileri düzeydedir.

Siyasi bakımdan Hun, Göktürk, Bulgar ve Sabirlerde örnekleri görüldüğü üzere kadınlar devletin her kademesinde görev yapabiliyorlard1. Mete'nin ya da İl Kağan'ın örneklerinde olduğu gibi devlet hayatı ile ilgili çok önemli kararlarda belirleyici olan kadınlar, eşlerinin kararını değiştirebiliyordu. Arıkan Hatun örneğinden anlaşıldığı kadarıyla hizmetinde memurları olan hükümdar hanımları tek başlarına elçi kabul edebilecek ve gelen heyetlere ayrıca ziyafet düzenleyebilecek hukuka sahipti. Uygurlarda mahkeme başkanlığı yapan kadınlara rastlanması kadınların verdiği hükümlerin toplumda itibar gördügünü gösterir. Nihayet Boğarık Hatun'un Sabir hükümdarı olarak görev yapması kadınların siyasi olarak tırmanabilecekleri en üst basamaktır. O dönemin şartlarında elde ettikleri bu hakları koruyabilselerdi kadınların günümüzdeki statüsü çok daha farklı olurdu.

\section{Kaynaklar}

Ahmetbeyoğlu, A. (1995). Grek seyyahı Priskos (V. Asır)'a göre Avrupa Hunları. İstanbul: Türk Dünyası Araştırmaları Vakfı Yayını.

Alyılmaz, S. ve Alyılmaz, C. (2014). Eski Türk kadın heykellerinin düşündürdükleri. Uluslararası Türkçe Edebiyat Kültür Eğitim Dergisi, 3/4, 1-33.

Banarlı, N. S. (1971). Resimli Türk edebiyatı tarihi. İstanbul: Milli Eğitim Bakanlığı Yayını.

Bang, W ve Rahmeti, G. R. (2012). Ŏğuz Kağan destanı, İstanbul: Örgün Yayınevi.

Ban-gu (2004). Han Hanedanlı̆̆ tarihi Hsiung-nu (Hun) monografisi. (A. Onat vd.), Ankara: Türk Tarih Kurumu Yayını.

Bars, M. E. (2014). Ak Kağan destanında kadın tipi. Uluslararası Türkçe Edebiyat Kültür Eğitim Dergisi, 3/3, 94-111.

Baştav, Ş. (1941). Sabir Türkleri. Belleten, V/17-18 (Nisan), 53-99.

Baykara, T. (1997). Türk Kültürü Araştırmaları. İzmir: Akademi Kitabevi. 
Chi, T. (1971). Türk tarihine aid Çin kaynakları. İstanbul Üniversitesi Edebiyat Fakültesi Tarih Enstitüsü Dergisi, 2, 181-210.

Çağatay, N. (1989). İslâm dönemine dek Arap tarihi. Ankara: Türk Tarih Kurumu Yayını.

Çoruhlu, Y. (2000). Türk mitolojisinin ana hatları. İstanbul: Kabalc1 Yayınevi.

Di Cosmo, N. (2002). Hun İmparatorluğu'nun kuruluşu ve yükselişi. Türkler, I, Ankara: Yeni Türkiye Yayınları. 709-719.

Donuk, A. (1980). Çeşitli topluluklarda ve eski Türklerde aile. İstanbul Üniversitesi Edebiyat Fakültesi Tarih Dergisi, 33, 147-168.

Donuk, A. (1988). Eski Türk devletlerinde idarî-askerî ünvan ve terimler. İstanbul: Türk Dünyası Araştırmaları Vakfı Yayınları.

el-Belâzurî (1987). Fütuhu'l-Büldan (M. Fayda). Ankara: Kültür ve Turizm Bakanlığı Yayını.

Ergin, M. (1988). Dede Korkut kitabı, I. İstanbul: Boğaziçi Yayınevi.

Eröz, M. (1977). Türk ailesi. İstanbul: Milli Eğitim Bakanlığı Yayını.

Gökalp, Z. (1990). Türkçülügü̈n esasları. Ankara: Kültür Bakanlığı Yayını.

Gökalp, Z. (1991). Türk uygarlı̆̆ı tarihi. İstanbul: İnkılâp Kitabevi.

Gömeç, S. (1997). Kök Türk tarihi. Ankara: Türksoy yayınları.

İbn Fazlan (1975). İbn Fazlan seyahatnâmesi. (R. Şeşen). İstanbul: Bedir Yayınevi.

İnan, A. (1976). Eski Türk dini tarihi. İstanbul: Kültür Bakanlığı Yayını.

İnan, A. (1998). Makaleler ve incelemeler, I. Ankara: Atatürk Kültür, Dil ve Tarih Yüksek Kurumu Yayını.

Kabaklı Çimen, L. (2008). Türk töresinde kadın ve aile. İstanbul: IQ Kültür Sanat Yayını.

Kafesoğlu, İ. (1998). Türk milli kültürü. İstanbul: Boğaziçi Yayınevi.

Kaşgarlı Mahmud (1999). Divanü Lûgat-it Türk tercümesi, III. (B. Atalay). Ankara: Türk Dil Kurumu Yayını.

Ligeti, L. (1986). Bilinmeyen iç asya. (S. Karatay). Ankara: Milli Eğitim Bakanlığı Yayını.

Onay, İ. (2012). Eski Türk toplumunda aile düzeni ve bunun dini, siyasi hayata yansımaları. The Journal of Academic Social Science Studies, 6, 347-357.

Orkun, H. N. (1987). Eski Türk yazıtları. Ankara: Türk Dil Kurumu Yayını.

Ögel, B. (1988). Dünden bugüne Türk kültürünün gelişme çağları. İstanbul: Türk Dünyas1 Araştırmaları Vakfı Yayını.

Ögel, B. (2002). Sino Turcıca Çingiz Han'in Türk müşavirleri. İstanbul: IQ Kültür Sanat Yayıncilik. 
Pugliese, G. (1957). Roma ailesine tarihi bir bakış. (Z. Umur). İstanbul Üniversitesi Hukuk Fakültesi Dergisi, 22/1-4, 339-349.

Sevinç, N. (1987). Eski Türklerde kadın ve aile. İstanbul: Türk Dünyası Araştırmaları Vakfı Yayın1.

Şen, S. (2008). Dede Korkut kitabı'nda kadına yönelik hitaplar. Turkish Studies, 3/2, 627-641.

Taşağıl, A. (2004). Göktürkler, III. Ankara: Türk Tarih Kurumu Yayını.

Turan, O. (1980). Türk cihan hakimiyeti mefkuresi tarihi, I-II. İstanbul: Nakışlar Yayınevi.

Uraz, M. (1994). Türk mitolojisi. İstanbul: Mitologya Yayınları.

Useev, N. (2012). Köktürk harfli Yenisey yazıtlarındaki kadını bildiren kelimelerin anlamına göre eski Türklerde kadın imajı. Dil Araştırmaları, 11, 57-66.

Yusuf Has Hâcib (2003). Kutadgu Bilig, II. (R. R. Arat). Ankara: Türk Dil Kurumu Yayını. 